\section{Identification of the Edible Fig 'Bianco del Cilento' by Random Amplified Polymorphic DNA Analysis}

\author{
U. Galderisi' ${ }^{1}$, M. Cipollaro, G. Di Bernardo, L. De Masi, G. Galano, \\ and A. Cascino \\ Centro di Ricerca Interdipartimentale di Scienze Computazionali e \\ Biotecnologiche (C.R.I.S.C.E.B.) and Istituto di Farmacologia e Tossicologia, \\ 2.a Università degli Studi di Napoli, Facoltà di Medicina e Chirurgia, Via \\ Costantinopoli 16, 80138 Naples, Italy
}

Additional index words. Ficus carica, molecular identification, PCR

\begin{abstract}
Random amplified polymorphic DNA (RAPD) analysis is currently used to estimate genetic relationships in plants. We have used RAPD analysis to distinguish six different cultivars of Ficus carica, and several of their clones, that are widespread in the Campania Region of Southern Italy. Among these cultivars, 'Bianco del Cilento' has unique characteristics, and is particularly useful for drying and for the manufacture of syrups. The protection of this cultivar is important to the Campania Region. We have utilized molecular markers to allow accurate identification of this cultivar, making it possible to control the quality of products and prevent fraudulent commerce. DNA was extracted from leaves and amplified by PCR using random oligonucleotide primers. The amplification patterns obtained with five decamer primers were useful for distinguishing all six cultivars analyzed. 'Bianco del Cilento' was identified by two primers. The banding patterns were scored and used in similarity value calculations to estimate genetic relationships.
\end{abstract}

Campania is the most important region in Italy for the production of edible figs (Ficus carica L.). The fig cultivar Bianco del Cilento has unique characteristics that make it particularly suitable for drying and syrup production, and is still used in herbal and dietetic preparations for its medicinal and therapeutic virtues (D’Alessandro, 1991). Protection of the cultivar is of major importance to the Campania Region, and thus DNA fingerprint techniques are of great interest for its proper identification.

The more widespread clonal variants of 'Bianco del Cilento' are designated clones 151,250 , and 356 . These originated in different areas of the Campania Region and have several morphological and/or phenological differences, such as fruit dimensions and flowering time. Some other fig cultivars that occur in the region include 'Dottato', 'Lumincedda', 'Melagrana', 'Petrelli', and 'Zecola'. Although

Received for publication 13 April 1998. Accepted for publication 11 May 1999. This work was partially supported by Consorzio per la Ricerca Applicata in Agricoltura (C.R.A.A.). We are very grateful to Istituto per il Progetto Italiano di Tecnologie Avanzate in Genetica ed Oligodesossi Ribonucleotidi Antisenso (P.I.T.A.G.O.R.A.), Naples, for the stimulating cultural support. The cost of publishing this paper was defrayed in part by the payment of page charges. Under postal regulations, this paper therefore must be hereby marked advertisement solely to indicate this fact.

${ }^{1}$ To whom reprint requests should be addressed. Phone and fax $++39++81$ 5665879; e-mail: galderisi@yahoo.com these cultivars do not have as great a commercial value as 'Bianco del Cilento', they also have clonal variants.

Methods for the identification of fig cultivars are primarily based on plant morphological traits. These, however, are generally unreliable indicators of plant genotype, and are influenced by environmental factors. It is now feasible to identify variations at the DNA level that are not necessarily expressed phenotypically. Such variations can be identified by RAPD (Hattemer, 1991; Kaneko et al., 1986; Powell et al., 1991; Sigurgeirsson et al., 1991), a DNA fingerprinting technique used to detect genomic polymorphisms. In the RAPD method, genomic DNA is amplified by polymerase chain reaction (PCR) under low stringency conditions using a single, short oligonucleotide primer of arbitrary sequence. The low stringency PCR conditions allow the primer to anneal to multiple sites on the genome, resulting in an array of amplified DNA fragments. Polymorphisms among individuals or closely related strains, such as different cultivars of a species, are detected as differences in banding patterns on an agarose or polyacrylamide gel (Caetano-Anolles et al., 1991; Castiglione et al., 1993; Demeke et al., 1993; Mulcahy et al., 1993).

Here we report the application of RAPD analysis to fingerprint the cultivar Bianco del Cilento as well as the other cultivars of our region. Furthermore, we used RAPD to assess whether intra-varietal phenotypic differences observed in 'Bianco del Cilento' and in the other cultivars have resulted from genetic diversity, or are due to environmental factors.
Plant material. The clones of Ficus carica analyzed in this study belong to the cultivars Bianco del Cilento (clones 151, 250, 356), Dottato (clones 71, 156, 4, 240), Lumincedda (clones 383, 74), Melagrana (clone 137), Petrelli (clone 176), and Zecola (clones 344, 264). All were from the collection of Vivaio Forestale di Foce Sele, Salerno, Campania Region, Italy. Each clone derives from a tree population that was obtained by vegetative propagation. The different populations are located in separate areas of Campania Region.

DNA isolation. Fresh fig leaves $(1 \mathrm{~g})$ from one plant of each clone were ground to powder in the presence of liquid nitrogen. The powder was dissolved in urea buffer $(0.35 \mathrm{M} \mathrm{NaCl}, 2 \%$ SDS, 50 mm Tris-HCl pH 8, 10 mм EDTA pH $8,7 \mathrm{~m}$ urea), extracted twice with phenolchloroform and precipitated with $100 \%$ ethanol. To achieve further purification, the resulting DNA pellet was dissolved in urea buffer, and the above described procedure was repeated. The resulting DNA was dissolved in distilled water and treated with $5 \mu \mathrm{g} \cdot \mathrm{mL}^{-1}$ of RNAse A for $60 \mathrm{~min}$ at $37^{\circ} \mathrm{C}$.

DNA amplification. We designed the twenty primers (U1-U20) that were tested in this study. Primers were obtained from Centro di Ingegneria Genetica(CE.IN.GE.), Naples, Italy (Table 1). To obtain satisfactory RAPD amplification patterns we tested Taq DNA polymerases from Promega (Madison, Wis.), Life Technologies (Paisley, U.K.), Boehringer Italia (Monza, Italy), and Perkin Elmer(Branchburg, N.J.).

The PCR reaction was performed in $50 \mu \mathrm{L}$

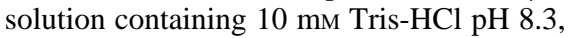
$10 \mathrm{~mm} \mathrm{KCl}, 3 \mathrm{~mm} \mathrm{MgCl}{ }_{2}, 200 \mu \mathrm{M}$ each of dATP, dCTP, dTTP, dGTP, 20 pmols of the primer, $2.5 \mathrm{U}$ of Taq DNA polymerase, and 10 ng of fig DNA. The mixtures were assembled at $0{ }^{\circ} \mathrm{C}$, then transferred to a Perkin Elmer thermalcycler, precooled at $4{ }^{\circ} \mathrm{C}$. Reactions were incubated at $94{ }^{\circ} \mathrm{C}$ for $3 \mathrm{~min}$ and DNA amplification was performed for 45 cycles. Each cycle was at $94^{\circ} \mathrm{C}$ for $1 \mathrm{~min}$, at $40^{\circ} \mathrm{C}$ for $1 \mathrm{~min}$, at $72{ }^{\circ} \mathrm{C}$ for $1 \mathrm{~min}$. Each PCR analysis was repeated from three to five times; only reproducible amplification patterns were utilized for further analyses.

Electrophoresis in agarose gel. The amplification products were separated by electrophoresis in $2 \%$ agarose gels in $1 \mathrm{X}$ TAE buffer (40 mm Tris-Acetate, 1 mM EDTA, pH 8.0) for $1 \mathrm{~h}$ at $100-120$ volts. The gels were stained with $5 \mu \mathrm{g} \cdot \mathrm{mL}^{-1}$ of ethidium bromide and photographed under UV light.

Similarity value calculation. Bands on agarose gels were scored as present or absent and a pairwise similarity matrix was constructed using the Dice coefficient: $2 c /(a+b+2 c)$ (Sneath and Sokal, 1973). The similarity values were calculated as the doubled number of bands (2c) shared between two patterns divided by the sum of all the bands in the same patterns, which comprises bands present in one of two patterns (a), bands present in the other one (b) and shared bands (c). 


\section{Results and Discussion}

Initial problems were encountered in the extraction of sufficiently pure DNA. The extraction methods based on a single step of purification in urea buffer (Doyle and Doyle, 1990) resulted in DNA unsuitable for PCR, and in fact no amplifications were obtained. A second treatment of DNA with urea buffer was essential to eliminate impurities, such as tannins, alkaloids, and flavones, present in the extract. These compounds can interact with the double-stranded DNA, interfering with PCR amplification (Bohm, 1987; De Jong, 1991; Godard et al., 1994; Mergny et al., 1992). In a PCR reaction performed with AmpliTaq DNA polymerase (Stoffel Fragment), single extraction with urea buffer of DNA (lane $a$ ) resulted in an absence of amplification, while double extraction (lane $b$ ) resulted in amplification products (Fig. 1). We also observed that RNAse treatment of the DNA preparation enhanced the reproducibility of PCR analysis (data not shown).

Different Taq DNA polymerases were tested in order to obtain satisfactory PCR amplification patterns. Under our PCR conditions, the Taq DNA polymerase from Promega, Life Technologies, and Boehringer Italia produced complex amplification patterns that were not readily reproducible. Use of Stoffel Fragment Taq DNA polymerase from Perkin Elmer, which lacks $5^{\prime}$ to $3^{\prime}$ nuclease activity, facilitated the creation of smaller PCR product with enhanced reproducibility. The same DNA target used above was amplified in a reaction buffer containing $1 \mathrm{~mm}$ (lane $b$ ), $1.5 \mathrm{~mm}$ (lane $c), 2 \mathrm{~mm}$ (lane $d$ ), or $3 \mathrm{~mm}$ (lane $e$ ) $\mathrm{MgCl}_{2}$, and reproducible amplification patterns were obtained over a broad range of magnesium concentrations (Fig. 1). Our optimized RAPD reaction also showed reproducibility among individual extractions of the same clone (Fig. 1 , from lane $f$ to lane $q$ ).

Polymorphisms were observed among the six cultivars of Ficus carica using the RAPD procedure. Although the primers U8, U12, and U18 produced conserved amplified DNA fragments common to all the cultivars, the other 17 primers, including U1, U3, U4, U11, and U14, yielded RAPD bands useful for identification. The number of amplified DNA products was cultivar- and primer-dependent. A minimum of one (primer U13) and a maximum of 15 (primer U2) DNA fragments were observed. The size of amplified DNA bands ranged from $\approx 200$ to 1400 base pairs (Table 1 ).

The combination of primer U1, U3, U4, U11, and U14 allowed us to distinguish all the cultivars of Ficus carica analyzed. In particular, 'Bianco del Cilento' was successfully identified by the RAPD fingerprint obtained with the primers U4 and U1. With primer U1 the 'Bianco del Cilento' clones 151, 250, and 356 (Fig. 2A, lanes $b, c$, and $d$ ) gave identical RAPD profiles, while the clones of the other cultivars, such as 'Lumincedda' 383 and 74 (Fig. 2A, lanes $i, k$ ), were quite different from each other.

With the primer U4, 'Bianco del Cilento' clones 151, 250, and 356 (Fig. 2B, lanes $b, c$,

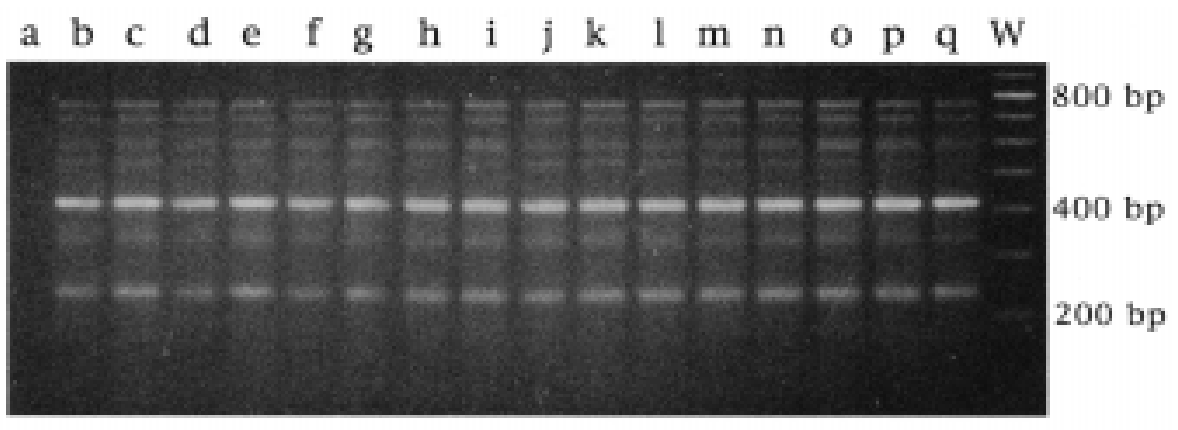

Fig. 1. Agarose gel electrophoresis of DNA fragments obtained by RAPD amplification of fig cultivar Bianco del Cilento with primer U18 and Stoffel fragment Taq DNA polymerase. Lanes $a, b, c, d, e$ : a single plant of clone 151; the procedure for the extraction of DNA was repeated once (lane $a$ ) or twice (lanes $b, c, d, e$ ) and the DNA amplification was performed in a buffer containing either $1 \mathrm{~mm} \mathrm{MgCl}_{2}$ (lanes $a, b), 1.5 \mathrm{~mm}$ (lane $c$ ), $2 \mathrm{~mm} \mathrm{MgCl}_{2}$ (lane $d$ ), and $3 \mathrm{~mm} \mathrm{MgCl}_{2}$ (lane $e$ ). Lanes $f, g, h, i$ : different individual plants of the clone 151; lanes $j, k, l, m$ : different individual plants of the clone 250; lanes $n$, $o, p, q$ : different individual plants of the clone 356. Lane $W: 100$ base-pair ladder as molecular marker.

Table 1. Primers with arbitrary sequence tested for their effectiveness in the RAPD analysis of fig DNA.

\begin{tabular}{|c|c|c|c|}
\hline Primer & Sequence & $\begin{array}{c}\text { No. } \\
\text { total DNA bands }\end{array}$ & $\begin{array}{c}\text { No. } \\
\text { polymorphic bands }\end{array}$ \\
\hline$\overline{\mathrm{U} 1}$ & 5'-AGGGGTCTTG-3' & 13 & 12 \\
\hline $\mathrm{U} 2$ & $5^{\prime}$-CAATCGCCGT-3' & 15 & 14 \\
\hline U3 & 5'-GGGTTTAGGG-3' & 6 & 4 \\
\hline U4 & 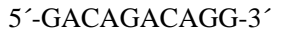 & 7 & 6 \\
\hline U5 & 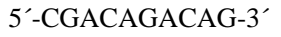 & 6 & 2 \\
\hline U6 & 5'-GGATGGATGG-3' & 9 & 2 \\
\hline U7 & $5^{\prime}-\mathrm{CACCACCACC}-3^{\prime}$ & 6 & 3 \\
\hline U8 & 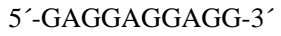 & 2 & 0 \\
\hline U9 & $5^{\prime}-{ }^{\prime}$ TGAGGGCT-3' & 3 & 1 \\
\hline U10 & 5'-GTCGCTCAGA-3' & 6 & 4 \\
\hline U11 & 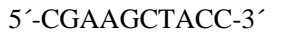 & 11 & 8 \\
\hline U12 & 5'-GTGGGGAGTT-3' & 3 & 0 \\
\hline U13 & 5'-CCAGTGCTCT-3' & 2 & 1 \\
\hline U14 & $5^{\prime}$-GGCCTATCGA-3' & 5 & 1 \\
\hline U15 & 5'-TCATCGCGCT-3' & 6 & 3 \\
\hline U16 & 5'-AGTGGCCTTG-3' & 5 & 1 \\
\hline U17 & $5^{\prime}$-CTGCCACGAT-3' & 4 & 1 \\
\hline U18 & $5^{\prime}-{\mathrm{TTCACCCACC}-3^{\prime}}^{\prime}$ & 7 & 0 \\
\hline U19 & 5'-TGGGAACGGT-3' & 6 & 2 \\
\hline $\mathrm{U} 20$ & $5^{\prime}$-GAATGGGAGG-3' & 9 & 3 \\
\hline
\end{tabular}

and $d$ ) produced different amplification patterns. Their profiles were also different from those of the remaining clones (lanes $a$ and $e-$ $m$ ). Other clonal variants were also identified with this primer. For example, the 'Lumincedda' clones 383 and 74 (Fig. 2B, lanes $i, k)$ were different from each other and from the clones of the other cultivars. Likewise, the 'Zecola' clones 344 and 264 (Fig. 2B, lanes $l, m$ ) were distinguishable from each other and from the other clonal variants.

The results of the amplified profiles shown in Figs. $2 \mathrm{~A}$ and $2 \mathrm{~B}$, along with the other RAPD profiles that we obtained, seem to indicate substantial genetic variability among cultivars. Furthermore, some of them, such as 'Dottato' and 'Lumincedda', exhibit genetic differences among the clones. 'Bianco del Cilento' appeared to be the most homogenous cultivar. To verify that only the clones of 'Bianco del Cilento' had substantial genetic homogeneity, a band-sharing analysis was performed. DNA bands on agarose gels were scored as present or absent and data obtained were used to produce the similarity matrix index (Table 2). The analysis of the matrix based on the Dice similarity indices indicates that the clones of the cultivar Bianco del Cilento are substantially homogeneous genetically (Dice index > 0.9). On the other hand, the clones of the other cultivars were more distinct from each other.

The very low level of heterogeneity observed among the clones of 'Bianco del Cilento' might indicate a common origin. This could be due to the clonal selection for high-quality fruits that has increased the exchange and the utilization of the same propagation material in different areas. The morphological and phenological differences observed among the 'Bianco del Cilento' clones could be due to the influence of either environmental or genetic factors. Natural mutations could have occurred, resulting in intra-cultivar phenotypic variability. Since we have analyzed only a small percentage of the fig genome, and have not set up appropriate multi-environmental trials, we are not able to determine which factor has had the main influence.

The RAPD fingerprints produced with primers U1, U3, U4, U11, and U14 allowed us to discriminate among all the Ficus carica cultivars present in the Campania Region, even among those that cannot be distinguished on the basis of morphological and phenological traits, such as 'Dottato' and 'Bianco del 


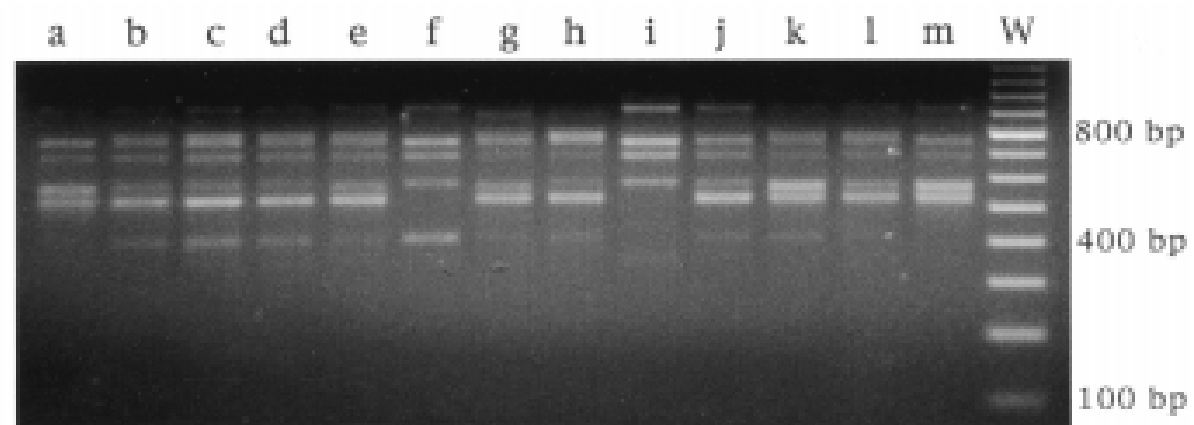

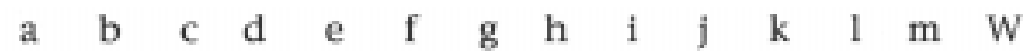

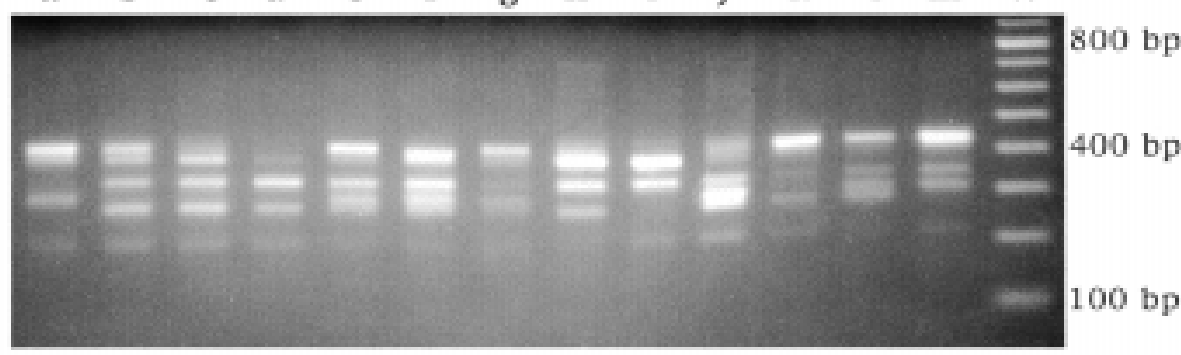

Fig. 2. (A, B) Agarose gel electrophoresis of DNA fragments obtained by RAPD amplification of different Ficus carica cultivars and clones with the primer U1 (A) or U4 (B) plus Stoffel fragment Taq DNA polymerase. $a$ - 'Dottato' clone 71; $b$ - 'Bianco del Cilento' clone 151; $c$ - 'Bianco del Cilento' clone 250; $d$ - 'Bianco del Cilento' clone 356; $e$ - 'Dottato' clone 156; $f$-'Dottato' clone 4; $g$ - 'Dottato' clone 240; $h$-'Petrelli' clone 176; $i$-'Lumincedda' clone 383; $j$-'Melagrana' clone 137; $k$ 'Lumincedda' clone 74; $l$ — 'Zecola' clone 344; $m$ - 'Zecola' clone 264; $W-100$ base-pair ladder as molecular marker.

Cilento'. Therefore, the use of molecular methods to identify fig genotypes is an efficient way to control the quality of products and to prevent fraudulent commerce.

In conclusion, the present study has demonstrated that RAPDs provide a single and reliable method for identification of Ficus carica cultivars, selected from the Campania Region in South Italy.

\section{Literature Cited}

Bohm, B.A. 1987. Intraspecific flavonoids variations. Bot. Rev. 53:197-279.

Caetano-Anolles, G., B.J. Bassam, and P.M
Gresshoff. 1991. DNA amplification fingerprint using very short arbitrary oligonucleotide primers. Biotechnology 9:553-557. Bisoffi and F. Sala. 1993. RAPD fingerprints for identification and for taxonomic studies of elite poplar (Populus spp.) clones. Theor. Appl. Genet. 87:54-59.

D'Alessandro, E. 1991. Il fico, prodotto tipico campano. Agricoltura Campania 4:10-18.

Demeke, T., L.M. Kawchuk, and D.R. Lynch. 1993. Identification of potato cultivars and clonal variants by random amplified polymorphic DNA analysis. Amer. Potato J. 70:561-571.

De Jong, H. 1991. Inheritance of anthocyanin pigmentation in the cultivated potato: A critical
Castiglione, S., G. Wang, G. Damiani, C. Bandi, S. review. Amer. Potato J. 68:585-593.

Doyle, J.J. and J.L. Doyle. 1990. Isolation of plant DNA from fresh tissue. Focus 12:13-15.

Godard, G., J.C. Francois, I. Duroux, U. Asseline, M. Chassignol, N. Thuong, C. Helene, and T. Saison-Behomoaras. 1994. Photochemically and chemically activable antisense oligonucleotides: Comparison of their reactivity toward DNA and RNA targets. Nucleic Acids Res. 22(22):4789_ 4795.

Hattemer, H.H. 1991. Genetic analysis and population genetics, p. 5-22. In: S. Fineschi, M.E. Malvolti, F. Cannata, and H.H. Hattemer (eds.). Biochemical markers in the population genetics of forest trees. SPB Academic Publishing, The Hague, The Netherlands.

aneko, T., T. Terachi, and K. Tsunewaki. 1986. Studies on the origin of crop species by restriction endonuclease analysis of organellar DNA. Jpn. J. Genet. 61:157-168.

Iergny, J.L., G. Duval-Valentin, C.H. Nguyen, L. Perroualt, B. Faucon, M. Rougee, T. MontenayGarestier, E. Bisagni, and C. Helene. 1992. Triple helix specific ligands. Science 256:16811684.

Iulcahy, D.L., M. Cresti, S. Sansavini, G.C. Douglas, H.F. Linskens, G. Bergamini-Mulcahy, R. Vignani, and M. Pancaldi. 1993. The use of random amplified polymorphic DNAs to fingerprint apple genotypes. Scientia Hort. 54:8996.

Powell, W., M.S. Phillips, J.W. McNicol, and R. Waugh. 1991. The use of DNA markers to estimate the extent and the nature of genetic variability in Solanum tuberosum cultivars. Ann. Appl. Biol. 118:422-432.

Rychlik, W., W.J. Spencer, and R.E. Rhoads. 1990. Optimization of the annealing temperature for DNA amplification in vitro. Nucleic Acids Res. 18:6409-6412.

Sigurgeirsson, A., A.E. Szmidt, and B. Karpinska. 1991. Alaskan Picea sitchensis populations infiltrates with Picea glauca genes: A study using DNA markers, p. 197-207. In: S. Fineschi, M.E. Malvolti, F. Cannata, and H.H. Hattemer (eds.). Biochemical markers in the population genetics of forest trees. SPB Academic Publishing, The Hague, The Netherlands.

Sneath, P.H.A. and R.R. Sokal. 1973. Numerical taxonomy. The principles and practice of numerical classification. Freeman, San Francisco.

Table 2. Similarity matrix based on the Dice index. ${ }^{2}$

\begin{tabular}{|c|c|c|c|c|c|c|c|c|c|c|c|c|c|c|}
\hline \multicolumn{2}{|c|}{$\overline{\text { Cultivar }}$} & $\mathrm{BCF}$ & $\mathrm{BCF}$ & $\mathrm{BCF}$ & $\mathrm{DF}$ & $\mathrm{DF}$ & DF & DF & $\mathrm{PF}$ & $\mathrm{LF}$ & LF & $\mathrm{MF}$ & $\mathrm{ZF}$ & $\overline{\mathrm{ZF}}$ \\
\hline \multicolumn{2}{|c|}{ Clone } & 151 & 250 & 356 & 71 & 156 & 4 & 240 & 176 & 383 & 74 & 137 & 344 & 264 \\
\hline$\overline{\mathrm{BCF}}$ & 151 & 1 & & & & & & & & & & & & \\
\hline $\mathrm{BCF}$ & 250 & 0.97 & 1 & & & & & & & & & & & \\
\hline $\mathrm{BC}$ & 356 & 0.92 & 0.94 & 1 & & & & & & & & & & \\
\hline DF & 71 & 0.76 & 0.73 & 0.68 & 1 & & & & & & & & & \\
\hline DF & 156 & 0.78 & 0.75 & 0.70 & 0.84 & 1 & & & & & & & & \\
\hline DF & 4 & 0.74 & 0.72 & 0.76 & 0.72 & 0.86 & 1 & & & & & & & \\
\hline DF & 240 & 0.66 & 0.64 & 0.66 & 0.66 & 0.77 & 0.68 & 1 & & & & & & \\
\hline $\mathrm{PF}$ & 176 & 0.78 & 0.81 & 0.83 & 0.64 & 0.74 & 0.68 & 0.68 & 1 & & & & & \\
\hline LF & 383 & 0.70 & 0.72 & 0.70 & 0.70 & 0.68 & 0.74 & 0.64 & 0.68 & 1 & & & & \\
\hline LF & 74 & 0.87 & 0.84 & 0.80 & 0.77 & 0.86 & 0.73 & 0.70 & 0.71 & 0.68 & 1 & & & \\
\hline $\mathrm{MF}$ & 137 & 0.83 & 0.82 & 0.78 & 0.79 & 0.82 & 0.78 & 0.66 & 0.74 & 0.73 & 0.82 & 1 & & \\
\hline $\mathrm{ZF}$ & 344 & 0.75 & 0.72 & 0.67 & 0.83 & 0.89 & 0.70 & 0.79 & 0.71 & 0.70 & 0.83 & 0.78 & 1 & \\
\hline $\mathrm{ZF}$ & 264 & 0.76 & 0.73 & 0.68 & 0.85 & 0.83 & 0.73 & 0.71 & 0.69 & 0.75 & 0.85 & 0.80 & 0.87 & 1 \\
\hline
\end{tabular}

${ }^{2}$ The Dice index ranges between 0 and 1 value. The maximum genetic homogeneity is $1 . \mathrm{BCF}=$ 'Bianco del Cilento' fig; DF = 'Dottato' fig; PF = 'Petrelli' fig; $\mathrm{LF}=$ 'Lumincedda' fig; $\mathrm{MF}=$ 'Melagrana' fig; $\mathrm{ZF}=$ 'Zecola' fig. 